The Influence of Its Geography on the People of the Aures Massif, Algeria Author(s): M. W. Hilton-Simpson

Source: The Geographical Journal, Vol. 59, No. 1 (Jan., 1922), pp. 19-34

Published by: geographicalj

Stable URL: http://www.jstor.org/stable/1781855

Accessed: 27-06-2016 04:11 UTC

Your use of the JSTOR archive indicates your acceptance of the Terms \& Conditions of Use, available at

http://about.jstor.org/terms

JSTOR is a not-for-profit service that helps scholars, researchers, and students discover, use, and build upon a wide range of content in a trusted digital archive. We use information technology and tools to increase productivity and facilitate new forms of scholarship. For more information about JSTOR, please contact support@jstor.org.

The Royal Geographical Society (with the Institute of British Geographers), Wiley are collaborating with JSTOR to digitize, preserve and extend access to The Geographical Journal 
determination. He unfortunately lost his life in Tibet, but his companion carried on after his death and did an excellent piece of work in exploring that region. The lecturer has given us some valuable information about an exceptionally interesting region. We are very much indebted to the Consular Service for the valuable work which they do on the borders of the Chinese Empire. There is a wide field for their energies there, and we hope that more of them will come to the Geographical Society and be trained in surveying and other subjects, so that the information that they can bring back will be of all the more value. I ask you to give a very hearty vote of thanks to the lecturer this evening for his most interesting and valuable address.

\section{THE INFLUENCE OF ITS GEOGRAPHY ON THE PEOPLE OF THE AURES MASSIF, ALGERIA}

\section{W. Hilton-Simpson}

\section{Read at the Meeting of the Society, 7 November I921.}

I CAN scarcely hope to lay before the Society any new facts in the 1 topography of the Aures massif in South-Eastern Algeria, upon the borders of the great desert; an area which has been mapped to the scale of $\mathrm{I}: \mathbf{2 0 0 , 0 0 0}$ by officers of the French Service Géographique de l'Armée.

This paper, therefore, can lay claim to be nothing more than an attempt to draw attention to the influence of the geography of the massif upon its Shawiya Berber inhabitants in the preservation of manners and customs, arts and crafts, many of which have disappeared from other more accessible regions of North Africa. In order to realize how such a conservative influence has been exercised by the country upon its inhabitants, we must call to mind the frontiers of the massif and the geography of its valleys, before proceeding to consider a few examples of those traces of ancient culture which are to be found among the Shawiya to-day.

The boundaries of the Aures are clearly defined. Its northern frontier, separating it from the high-level plateau some 2800 feet above sea, upon which stand the ruins of the Roman camp of Lambessa and city of Timgad, consists of a barrier of steep wooded slopes leading up to the ridge of Mahmel, 7620 feet, and the peaks of Ishmul, 6800 feet, and Shelya, 7630 feet above sea-level, which mountains, capped with snow during a great part of the year, form the watershed of the massif. This frontier provides the Shawiya with an excellent line of defence in the north, running from west to east between the modern French towns of Batna and Khenshela on the plateau.

The southern wall of the Aures, the barren rocks overlooking the Sahara, whose wonderful coloration at sunset delights the eye of the visitor to Biskra, offers scant hope of success to an invader approaching from the desert, for the streams flowing from the high northern ridges 
of the hills to lose themselves in the Sahara emerge from the massif through narrow gorges bordered by precipitous cliffs, their waters liable to rise in sudden flood when rain has fallen or snow has melted on the watershed; and such tracks as avoid the river-bed are narrow, steep, and easily defensible. From the neighbourhood of Biskra in the west, then, to the oasis of Khanqa Sidi Naji in the south-eastern corner of the massif, the region is well protected by its southern geographical boundary.

From the oasis of Khanqa Sidi Naji the great bare ridge of the Jebel Shershar runs north-eastwards towards the plateau to the east of Khenshela, attaining an altitude above sea-level of 5870 feet, and forming a mighty bastion to guard the massif from the incursions of the nomad tribes, themselves Berbers, who wander over the country to the east of the Aures.

The western frontier of the massif, beneath which now runs the railway from Batna to Biskra, though, as seen from the train, it may appear less clearly defined than the other borders of the Aures, is in reality rugged and steep enough to oppose an almost impassable barrier to an enemy approaching from the west, for its rocky walls are penetrated by but one deep defile-that which leads eastward to the valley of $\mathrm{Bu}$ Zina in the hills from a point near the railway at Ma'afa.

The frontiers of the Aures massif, then, are such as to favour within them the survival of ancient customs among its Berber inhabitants. The physical features of the country, so shut off from the outer world, provide a series of natural ramparts for the protection of the Shawiya within what we may term their outer walls. Thus, in the north-west the rocky amphitheatre of Mahmel protects from the north and partially encloses the high-lying valley of $\mathrm{Bu} \mathrm{Zina}$, in which rises the stream of the same name; a valley surrounded by precipitous rocky hills penetrated by two narrow gorges, the defile of $\mathrm{Ma}^{\prime}$ afa leading to the west, and a deep ravine beneath the heights of a sacred mountain, known as the Jebel Bus, through which the Wad Bu Zina flows south to its confluence with the Wad Abdi at the important village of Menaa. Immediately to the east of the $\mathrm{Bu}$ Zina valley and separated from it by a rocky ridge-a spur of Mahmel-lies that of the Abdi stream.

Rising at the eastern foot of Mahmel, it flows in a south-westerly direction to join the $\mathrm{Bu}$ Zina river at Mena'a, through a valley (containing numerous villages) which, like that of Bu Zina and its eastern neighbour the Wad el Abyod, closely resembles a district of southern Europe. The gardens beside its stream are plentifully besprinkled with apricot, peach, and almond trees, as well as with walnuts and figs; the slopes which border it are studded with juniper and ilex.

The rocky chain separating the Abdi valley from that of the Wad el Abyod (in which chain the peaks of Azraq overlooking Mena'a rise to a height of some $635^{\circ}$ feet above the sea) contains high valleys and upper slopes clothed in forests of pine and cedar (the home of Sics scrofa, 


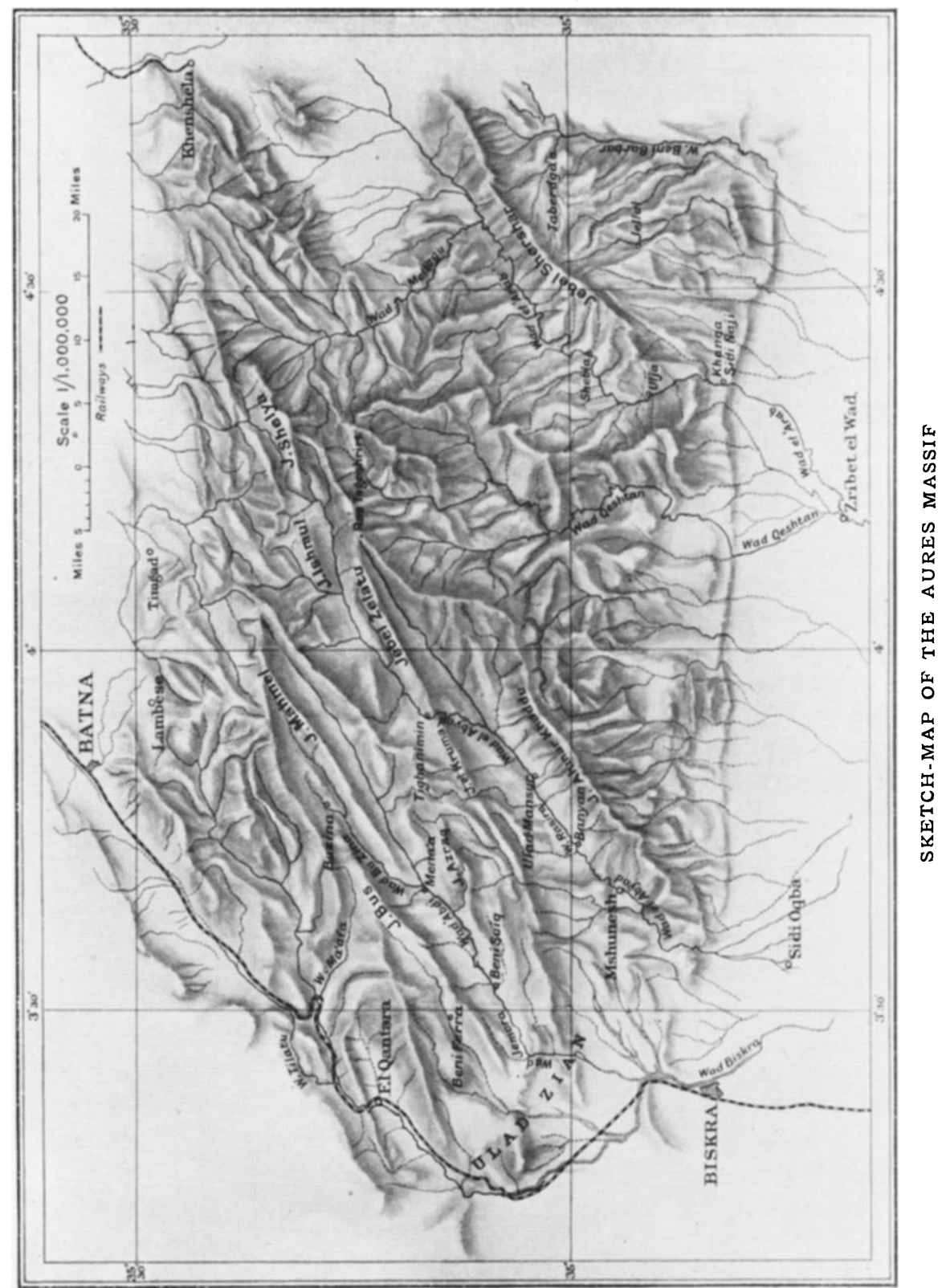

This content downloaded from 137.99.31.134 on Mon, 27 Jun 2016 04:11:07 UTC All use subject to http://about.jstor.org/terms 


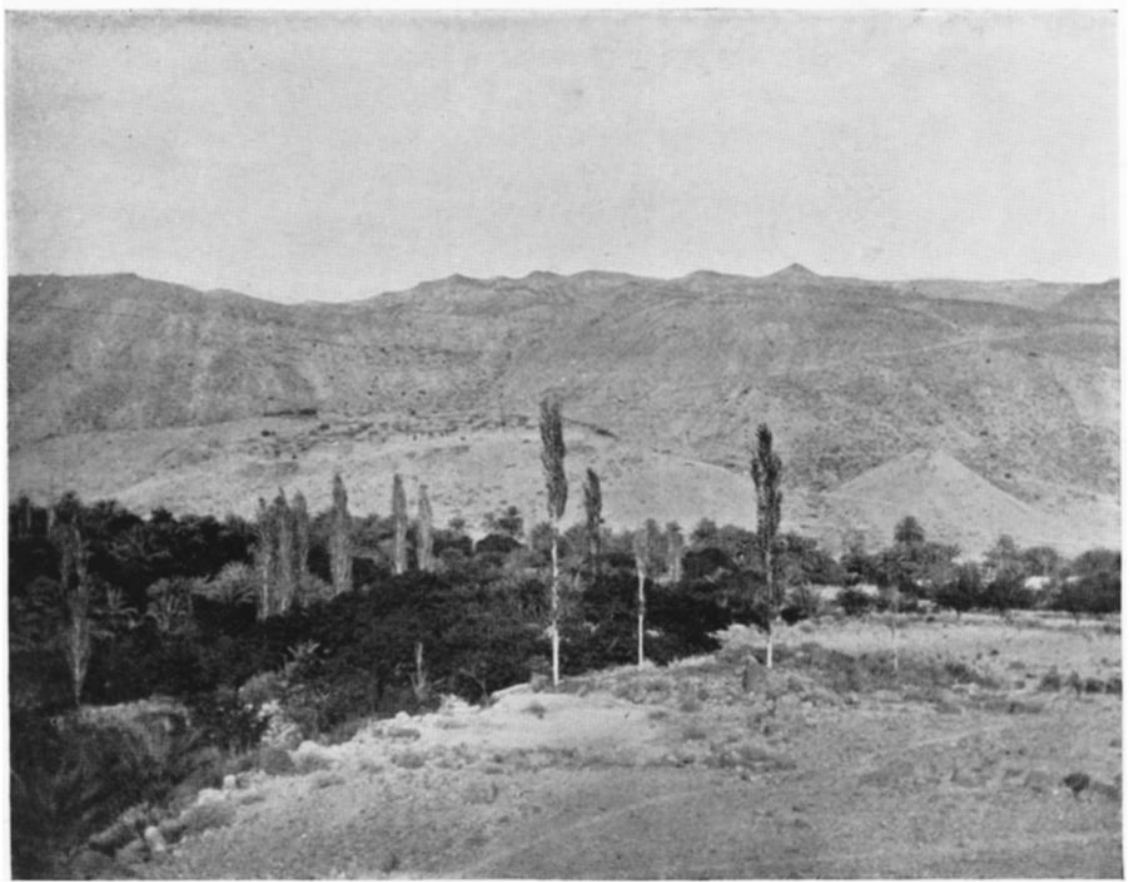

SHEBLA VILLAGE FROM THE SOUTH-WEST

Jebel Bus

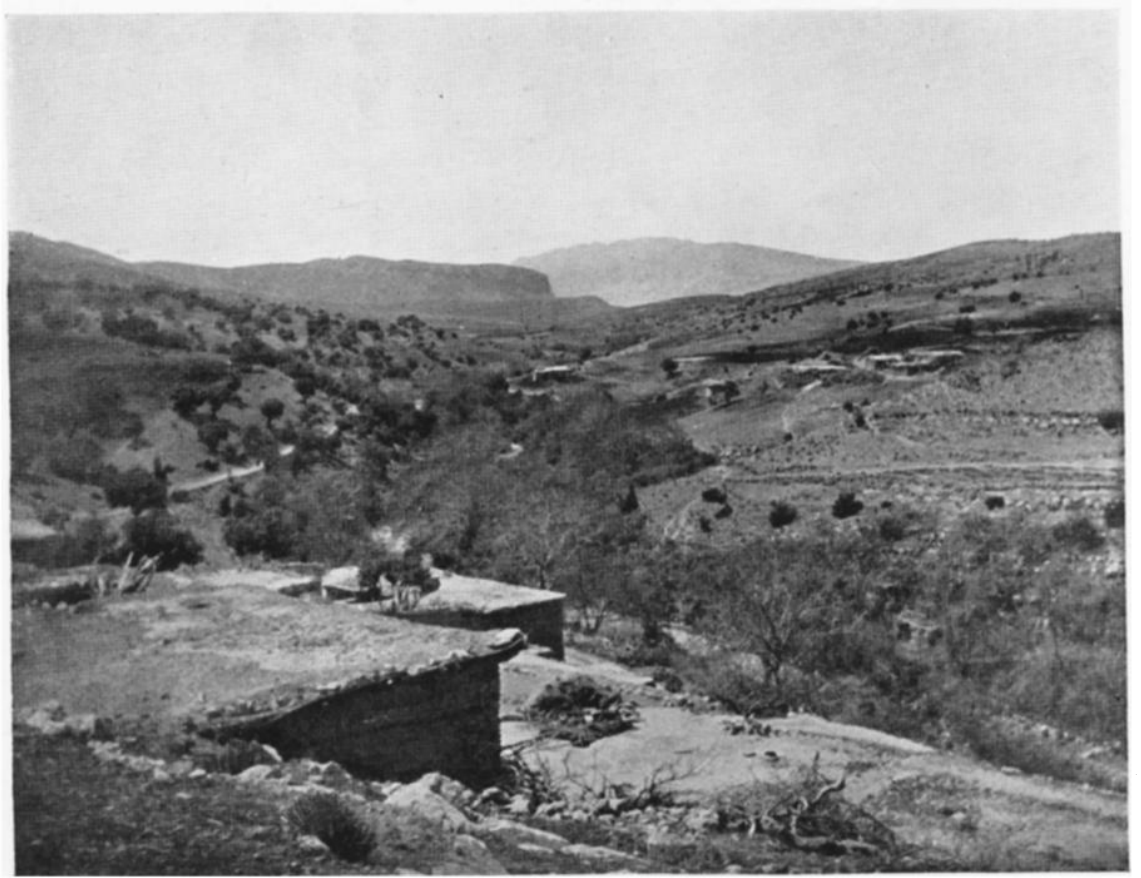

BU ZINA VALLEY LOOKING SOUTH.WEST FROM TIJGAD

This content downloaded from 137.99.31.134 on Mon, 27 Jun 2016 04:11:07 UTC All use subject to http://about.jstor.org/terms 
the European wild boar), whence distant views of the snows of Ishmul to the north provide glimpses of scenery more suggestive, perhaps, of an Asiatic hill country than of mountains upon the fringe of the African desert.

But in descending the Wad Abdi from Mena'a, riding largely in the bed of the stream, the traveller finds that in a space of some 12 miles as the crow flies he has left behind him the European scenery of the country about Mena'a, and, having passed between ruddy cliffs in the gorge just to the north of the little date oasis of Beni Suiq, he emerges into a wide and typically North African desert valley at Jemora, where the stream, meandering through groves of many thousands of date palms, flows on to the Sahara between ranges of hills devoid of vegetation, whose rocks glow at evening in all those successive shades of orange, pink, and purple which combine to form the glory of a sunset upon barren desert hills. In these 12 short miles he has left a land of fair-haired Berbers for a desert valley dotted with the tents of the Ulad Zian nomads, boasting of an Arab descent; he has exchanged the woodland home of the wild boar for the barren plains and foothills which afford meagre sustenance to the Dorcas and Cuvier's gazelles, and the bare crags among which may be sought Ovis Lervia, the Barbary sheep. I have nowhere met with so sharp a contrast in peoples, fauna, and flora as that to be found in the short space between Jemora and Mena'a.

The Wad el Abyod, the valley of which lies to the east of the Wad Abdi, also flows from north-east to south-west, rising at the foot of Shelya and passing beneath the southern slopes of Ishmul. For the northern part of its course this river valley resembles closely enough that of Abdi above Mena'a; but at a point near the centre of its course it turns to the south, and, flowing through the chasm of Tighanimin, the only cleft in its south-eastern wall (a ridge known as Zelatu above this gorge, where it reaches 5670 feet, and Kruma-4960 feet-to the south-west of the ravine), it emerges into a basin, some miles in width, which forms a sort of hinterland between the European scenery of its upper course and the Africa of its lower reaches.

From this basin onwards the stream, hence known as tbe Wad Rasira, runs south-westward through a wide valley between the ridge of Kruma to the north-west and that of Ahmar Khaddu-meaning the "Red-cheeked Mountain" from its hues at sunset-to the south-east, this wall of the valley attaining an altitude of some 6320 feet above sea-level. The ridges of Zelatu and Ahmar Khaddu, branches of a common stem known as the Ras Tageshrirt-6480 feet-enclose this valley and the basin at its head from the north and north-east, as does Mahmel that of Bu Zina. In the centre of this wide valley the stream has cut for itself a ravine which must, I think, rank first among the scenic wonders of the Aures, if not of the whole of Algeria.

The traveller crossing the valley from side to side sees nothing of the 
river nor any outstanding feature to break the barren monotony of surroundings described by Colonel Lartigue as "un pays épouvantable, où il semble que les pierres ont plu en deluge," until suddenly he finds himself upon the brink of a narrow chasm, at the foot of whose precipitous cliffs the Rasira stream flows through a belt of date palms, which the depth of the cañon reduces to the proportion of mere oleander bushes to the eye of the beholder from the brink of the great ravine. Clinging like eagles' nests to the rim of the cañon, overlooking their plantations below them, are to be seen numerous Shawiya hamlets, their houses built flush with the edge of the cliff from which, at a distance, they are scarcely distinguishable. This cañon of the Rasira, throughout its dozen miles of length, is marvellous in its grandeur and wild beauty.

Upon emerging from its cañon the river enters broken country, in which it waters a large date oasis at Banyan, before entering another but shorter gorge-a deep cleft in a solid wall of rock, which forms the central gateway of the southern Aures, through which it passes to the oasis of Mshunesh on the edge of the Sahara. Thus it will be seen that the western and central portions of the Aures are subdivided by rocky ridges into a series of valleys, each approached by but one or two deep defiles, which valleys may be likened to small fortresses within the natural walls which guard the massif as a whole.

To the east of Ahmar Khaddu, of which the eastern face is very precipitous, lies a tangle of lower foothills and valleys, through one of which the Wad Qeshtan flows from the Aures to the desert, an area far less densely populated than the country to the north-west of the Redcheeked Mountain, its inhabitants mostly leading a nomadic life.

We did not, therefore, visit these lesser valleys, for we preferred to seek out the Shawiya villages upon either side of the Jebel Shershar, the eastern bastion of the Aures. Beneath the western slopes of this ridge the most considerable of the poor Aures streams, known as the Wed el Arab, flows through a remarkably barren country until it reaches the Sahara at the oasis of Khanqa Sidi Naji after passing through a defile of the same name.

This valley, too, contains but few villages, for many of its inhabitants move up and down the barren hills with their flocks of goats and sheep according to the season and the state of the pastures : as happens also east of the ridge of the Jebel Shershar, where the Wed Beni Barbar flows southwards through the foothills to the desert. But though many of them lead a nomadic or semi-nomadic life, the inhabitants of the slopes of Jebel Shershar are Shawiya; and in such villages as they possess we found that Berber culture could be studied.

In the belief that in such an environment as I have attempted to describe we should be likely to find the Berber as little altered by the successive waves of conquest which have swept over North Africa as anywhere in Algeria, my wife and I selected the Aures massif as the field for 
our ethnographical work. Making our base at the little inn of El Qantara on the railway to the south-west of the hills, we undertook each year a series of journeys in the mountains, returning between them to El Qantara to replenish our stores. We travelled light. Accompanied by no servants other than a native mounted orderly, whose services the French authorities have always kindly placed at our disposal, we carried with us sleepingvalises, and but few stores. Relying for accommodation upon the neverfailing hospitality of the Qaids and the headmen of smaller villages, we found that we could enjoy better opportunities of studying Berber life by actually living in native houses in the villages than if we encamped outside them, opportunities which fully compensated us for the discomforts we often had to face.

Apart from the physical characteristics of the Shawiya, the fair skins and hair and the blue eyes so commonly to be seen among them, and the old Berber tongue which they speak but can no longer write, with neither of which we were directly concerned, the first outstanding difference between a village of the Aures and one of the plains which forced itself upon our notice lay in the construction of its houses. These are built of stone ; mud and straw, sun-dried bricks, as used in the desert, are not to be seen in a true Shawiya village, though from east to west across the southern Aures walls built of such bricks, especially in new houses, may be found, showing how the building of the desert has encroached upon the land of the Berbers, advancing up the course of their streams; but this sign of a tide of foreign culture has flowed but a very short distance into the hills, having merely lapped around the edges of this island of Berber culture.

A close examination of dwellings in all parts of the Aures has shown that, within the massif, is exemplified every stage in the evolution of the human habitation from the simple unprotected cave to the multi-storied stone-built defensible granary, known as a "qal'a," which is so noticeable a feature of southern Shawiya settlements to this day.

The Shawiya goatherd, often obliged to spend some time away from his village, usually bivouacs beneath a projecting rock or in a cleft in the rocks on a hillside. Should his stay there be of long duration he will be joined by his family and by his friends with their families, the little colony protecting themselves from the mountain winds by erecting a screen of brushwood in the opening of their cave or cleft. Examples of these caves, occupied during a great part of the year, are to be found in the gorge of Tilatu and near Beni Ferra in the south-west of the massif, as well as in many other districts of the hills. In other cases the screen of bushes is replaced by a wall of stones, partly closing the entrance to the cave, as in many dwellings of the Rasira valley, and this walling-up of the entrance has developed until it reaches the stage of the completely walled-in caverns of $\mathrm{Ma}^{\text {'afa }}$ and the lateral clefts in the cliff-face of Takarbust, in the Ma'afa defile, which, entirely closed by well-built walls on their open 
side, form snug and weather-proof cave-dwellings in the almost inaccessible face of a cliff.

The cave-dwelling Shawiya, dissatisfied with the irregular shape of the natural back of his home, at some time began to "square" this by means of masonry at the back and sides of his dwelling, as may be seen at Ma'afa, thus providing himself with a house of which the roof and floor only were of natural rock. Then, when the ledge on which he lived was wide enough to permit of such an extension, he threw forward his outer wall, connecting the top of this wall with his cave by means of a roof of mud supported upon rafters of juniper and laths of twigs. Such dwellings, half-house, half-cave, are to be found inhabited at Tilatu. And so by easy stages throughout the Aures we find the house gradually extending forward from the cave or excavation in a steep hillside until it stands alone on level ground, the typical rectangular Shawiya house of stone.

The finished house, to the somewhat rickety walls of which stability is lent by the insertion of one or more courses of beams resting upon strata of sticks running transversely through the wall, is usually built of untrimmed stones held together with mud, but trimming of the stone is practised in the Bu Zina valley, where houses are better and more regularly built than elsewhere, possibly owing to the neighbourhood of the Roman centres of Lambessa and Timgad beyond the ridge of Mahmel, whence settlers penetrated the Aures and may well have left their mark upon the buildings.

In dwellings too large to be spanued by single branches of the small local juniper (Juniperus phonicea) the rafters of the roof are supported upon pillars of that wood. 'The roof, except in certain cases in the south, where Arab influence may have produced some effect, is not surrounded by a parapet, for the Shawiya do not keep their women from the gaze of passers-by, and a parapet would hinder the removal of snow in the higher villages, with consequent damage to the roof. Beyond cooking-pots, a twin-stone quern, a basket slung from the roof to form a cradle, and a loom, the houses contain nothing which can be termed furniture, the family usually sleeping upon a platform of sticks beneath which their domestic animals pass the night.

As regards their general condition we can, from a now considerable experience, thoroughly endorse the statement of Leo Africanus which refers to a Berber people of Morocco: "Their houses are very loathsome, being annoied with the stinking smell of their goates ... neither sawe I euer, to my remembrance, greater swarms of fleas than among this people."

Before examining the continued growth of the house from one to several stories we may digress for a moment to seek the reason for this expansion. In order to protect themselves and their grain from attentions of roving bands from the hungry desert which might be driven by famine to cross the rugged boundaries of the massif in search of plunder, 
the Shawiya, especially in the southern portion of the Aures, even now construct their villages with a view to defence, almost invariably placing them high upon the angles formed by the junction of tributary ravines with a main valley, sites with which the geography of their country has liberally supplied them.

In describing Jugurtha's stronghold near the "Muluccha" [Muluya] river (on the Algerian-Morocco border) Sallust has been translated as follows: "There rose amid the surrounding plain a rocky mountain, broad enough at the summit for a fort of moderate size, and reaching to an immense height. A single narrow approach was left; all the rest was as precipitous naturally as if labour and design had been employed to form it." And, farther on, "the path used by the garrison was extremely narrow, with a sheer descent on either side."

There are to be found in the Aures to-day a large number of Shawiya villages to which this description applies with remarkable accuracy. At Ulad Mansur upon the eastern lip of the Rasira cañon, the village is built upon the apex of a rocky angle at the junction of two ravines and can be approached by mules by but one track, winding up from the valley below to the single gateway of the village granary or "qal'a"; though pedestrians in single file can follow a precipitous track resembling a flight of roughhewn steps up the very knife-edge of the spur, this path ending in a shaft through the rock up which the foot passenger must struggle to emerge in the village itself.

Jellal, beneath the eastern slopes of the Jebel Shershar, is built, as is Ulad Mansur, with the walls of its houses rising flush with the edges of the precipitous promontory, or rather twin promontories, on which it stands; access to the settlement is possible from one side only, and that side defended by the walls of its rearmost houses.

Taberdga, a few miles to the north of Jellal, crowns the summit of a steep knoll at the junction of three ravines, this knoll being approachable by means of a path following a cleft in the precipitous side of the mountain to which it is joined by an isthmus of rock, no more than ro yards in width, a cleft so small that the mule rider must lean low over his animal's withers to protect his head from the overhanging rocks, a chasm some 300 feet in depth yawning beneath him at one side. The isthmus itself is spanned by walls and the village gateway, beside which cliffs fall sheer to the ravines below on either hand. Any one of these three villages, selected merely as examples, would seem to fall in exactly with Sallust's description of a Numidian stronghold of 2000 years ago.

Obviously the restricted area of the apex of a spur could not long stand the increase of population in one-storied huts. Indeed, the very position of the huts built upon the uneven surface of a spur with the floor of one often upon the same level as the roof of its neighbour below it, would naturally lead the Shawiya to transform the terrace-roof of a single apartment into the floor of a building above it by simply increasing the 
height of their walls. Houses thus built are very common in the southern Aures; in fact, we lived in such an one at Ulad Mansur.

Need for economy of space also doubtless called the attention of the Shawiya to the fact that it was as easy to throw rafters and floors across their narrow lanes as to put roofs upon their houses, so that it was but a step from the construction of two-storied buildings to the multi-storied structure with covered lanes which, with more or less uniform outer walls and approached as a rule by a single gateway, constitutes the qal'a, or defensible granary, which is a feature of so many southern Aures villages to-day, and which may fairly be supposed to be the direct descendant, probably but little changed, of Jugurtha's "fort of moderate size" or "treasure house" described by Sallust so many centuries ago; a structure preserved in the fastnesses of the Aures that has disappeared from other more accessible regions of Algeria.

The qal'a, the evolution of which from a single-storied hut seems to be clearly attributable to the natural features of its site, is still used as a storehouse, but to a decreasing extent as a dwelling, for the settled conditions prevailing under the French are inducing the Shawiya to build outside the precincts of their village forts and even to descend into the valleys below them.

In order to stock their granaries the Shawiya cultivate every possible foot of land in their narrow valleys, and the irrigation of their fields has led to the continuance in use in some villages of a primitive type of waterclock for apportioning the limited supply of water available. The system of irrigation employed in the Aures and in such of the oases at the foot of the hills as are watered by more or less perennial streams is simple.

The stream is tapped by means of barrages, or lines of boulders placed obliquely across the watercourse, so that a portion of the stream is deflected into narrow artificial channels, known in Algeria as saqiyas, which conduct the water through the area to be irrigated. The main saqiyas, after supplying branch channels, each watering a group of gardens, discharge their residue of water into the river. This system has been developed until each group of gardens contains a network of miniature canals carried across depressions, and sometimes, as at Beni Suiq in the south-western corner of the massif, across their parent river, in wooden aqueducts often made of the hollowed stems of date-palms. These saqiyas, which are simply dug in the soil without reinforcement of their sides, require constant surveillance to counteract the silting which occurs in them after heavy rain has fallen or snow has melted on the watershed of the Aures; in some districts, therefore, an official is placed in charge of each branch saqiya, whose duty it is to exercise this surveillance and to call upon the riparian owners to make good such damage as it occurs, each landed proprietor being also responsible for the upkeep of a proportion of the barrage in the river whence he indirectly obtains his watersupply. The construction of a new saqiya, now the care of the French, 
appears formerly to have been undertaken by some important chief or wealthy native who received as much as two-thirds of the palms in the newly irrigated area as a reward of his outlay and initiative.

As we have seen already, the main streams of the Aures flow southwards from the watershed in the north of the massif to lose themselves in the desert; upon the quantity of water allowed to come out of the hills, therefore, oases such as Sidi 'Oqba and Zribat el Wad on the edge of the desert depend for the production of the dates necessary for the subsistence of many nomad tribes. Nowadays this amount is controlled by the French, but before their arrival any village of the hills had the right to as much water as its people cared to use regardless of the requirements of their neighbours lower down the river's course, provided that they allowed such water as they did not make use of to return to the parent stream. Messieurs Hanoteau and Letourneux ('La Kabylie,' 2, 25 I) expressly state that this right was held also by the Berbers of the coastal mountains, and Colonel Lartigue ('L'Aurès,' pp. 438, 439, and 445) shows that the Shawiya were in the habit of exercising it. It is evident, therefore, that disputes arising from the vital question of water-supply must have been frequent and probably sanguinary, not only between the Berbers of the hills and the nomad Arabs of the desert, but also between neighbouring Shawiya settlements, and would also have disturbed the peace of individual villages had not the clepsydra or water-clock of ancient times been kept in use to apportion its division.

When the day arrives on which the waters of a main channel are to be turned into a given one of its branch saqiyas (an operation performed without the aid of gates by merely blocking the main channel with earth and cutting an outlet in its side to connect it with the branch) owners of the gardens watered by the latter repair to a point overlooking their land, bearing with them the water-clock by means of which their periods of irrigation are to be timed.

The quantity of water to which each is entitled varies, for it is purchased, apart from the purchase of his land, by each individual farmer, who leaves it as he desires at his death and who may lend or sell any or all of his period of irrigation as he wishes. From 120 to 150 francs for one hour's uninterrupted flow of a branch saqiya every twenty days in perpetuity was stated in 1920 to be the price of irrigation at Beni Ferra.

As the side of the saqiya is cut to admit the water to the first garden to be irrigated, the water-clock, a small bowl of copper or zinc perforated in the centre of its bottom by a minute hole, is carefully placed upon the surface of a pail or earthen jar of water in which it automatically sinks as water enters through the hole. Each owner of land is entitled to so many sinkings of the clock, rather than to any definite number of hours or minutes of irrigation; the clock, therefore, is refloated the moment it sinks, and a pebble is placed on the ground by the individual manipulating the clock to indicate that the farmer has received his first sinking, an 
additional pebble being added to record his score each time the clock is refloated. Meantime a workman, who has been regulating the flow of the water over the garden or field, which is usually subdivided into rectangular patches by means of very small banks of earth to assist him in his task, is ready on the instant to stanch the rush of water from the saqiya when the owners beside the clock shout to him that his period is at an end; the water is then at once admitted to the next garden to be irrigated.

This division of water, carried out in the presence of the owners concerned and usually of a member of the village council, seems to be considered as equitable by the Shawiya. The clock itself is usually the property of the village council, and so is regarded as the legal measure. The official bowls appear to sink once in fifteen minutes, those I tried being fairly accurate; but there are in existence a number of privately owned clocks, used unofficially between friends, the time of whose sinking varies. Thus the bowl I collected, now in the Pitt-Rivers Museum, sinks once in about ten minutes, while a specimen from Tolqa on the edge of the desert, collected by Mr. W. J. Harding-King, who has most kindly supplied me with very full notes upon it, varied in its time of sinking from four minutes nine seconds to four minutes four seconds in a series of nine tests, excluding the first test, in which, the clock being dry, the time was about twenty seconds longer.

Mr. Harding-King's clock differs in form from the one I collected. My specimen, which I experienced great difficulty in obtaining, consists of a circular bowl of hammered copper; its side about I millimetre thick, its diameter $5 \frac{7}{8}$ inches at the lip and 6 inches at the bottom, which is slightly convex, the depth of the vessel being $2 \frac{1}{8}$ inches at the side and $2 \frac{1}{4}$ inches at the centre. It weighs 16 ounces.

Mr. Harding-King tells me that his specimen closely resembles my own in size and shape, save that its diameter is slightly larger at the bottom than at the top, and that its bottom is slightly more convex than that of my specimen. Both specimens are made of copper of the same thickness, and the bottoms and sides of both appear to be similarly joined by dovetailed edges. Some of the dovetails in the Tolqa specimen, however, appear to consist of separate pieces of copper distinct from both bottom and side.

The perforation for the inlet of water in the Tolqa clock $\left(3^{\circ} 5 \mathrm{~mm}\right.$. diameter) is greater than in my Beni Ferah example ( $\mathrm{I} \mathrm{mm}$. diameter), and Mr. Harding-King's bowl is fitted on the inside with a vertical tube, some $\frac{3}{4}$ inch in height and $\frac{3}{16}$ inch in diameter, which is fixed to the bottom of the bowl, and is intended, as Mr. Harding-King has stated in the Geographical Fournal, vol. 50, p. 36r, to regulate the flow of the incoming water. It is in this tube that the greatest difference between our clocks is to be found, and, although a native once attempted to describe to me a clock fitted with a tube, I was unable to follow his vague description, and I have found no such clock myself. 


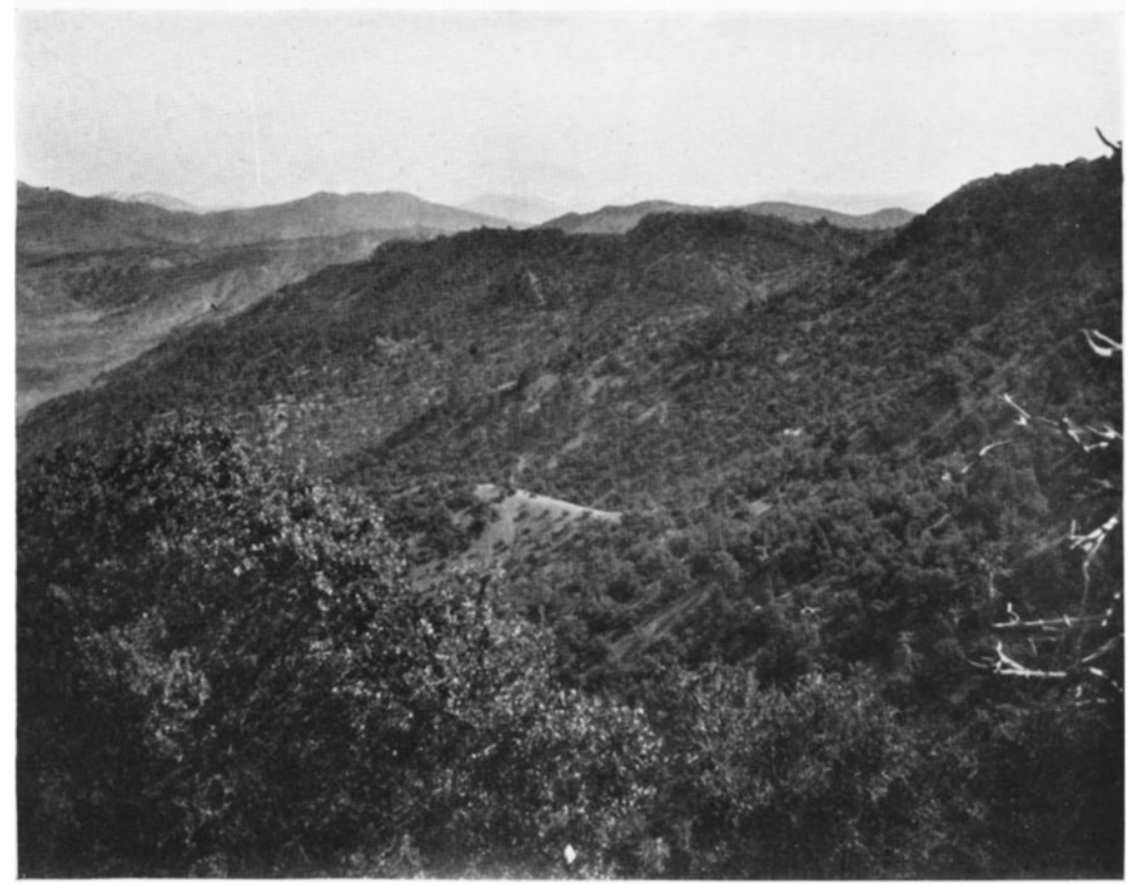

ISHMUL FROM THE NORTHERN SLOPES OF AZRAQ

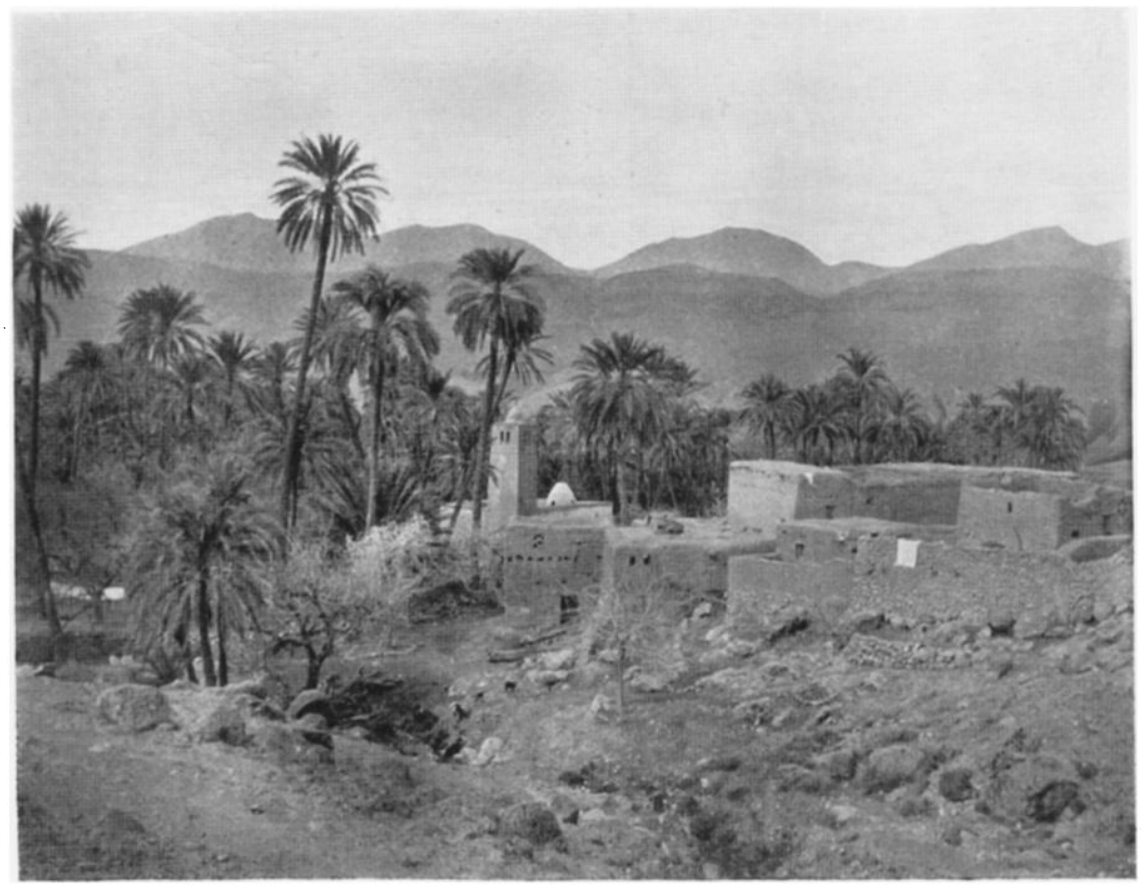

LOOKING NORTH FROM JEMORA

This content downloaded from 137.99.31.134 on Mon, 27 Jun 2016 04:11:07 UTC All use subject to http://about.jstor.org/terms 

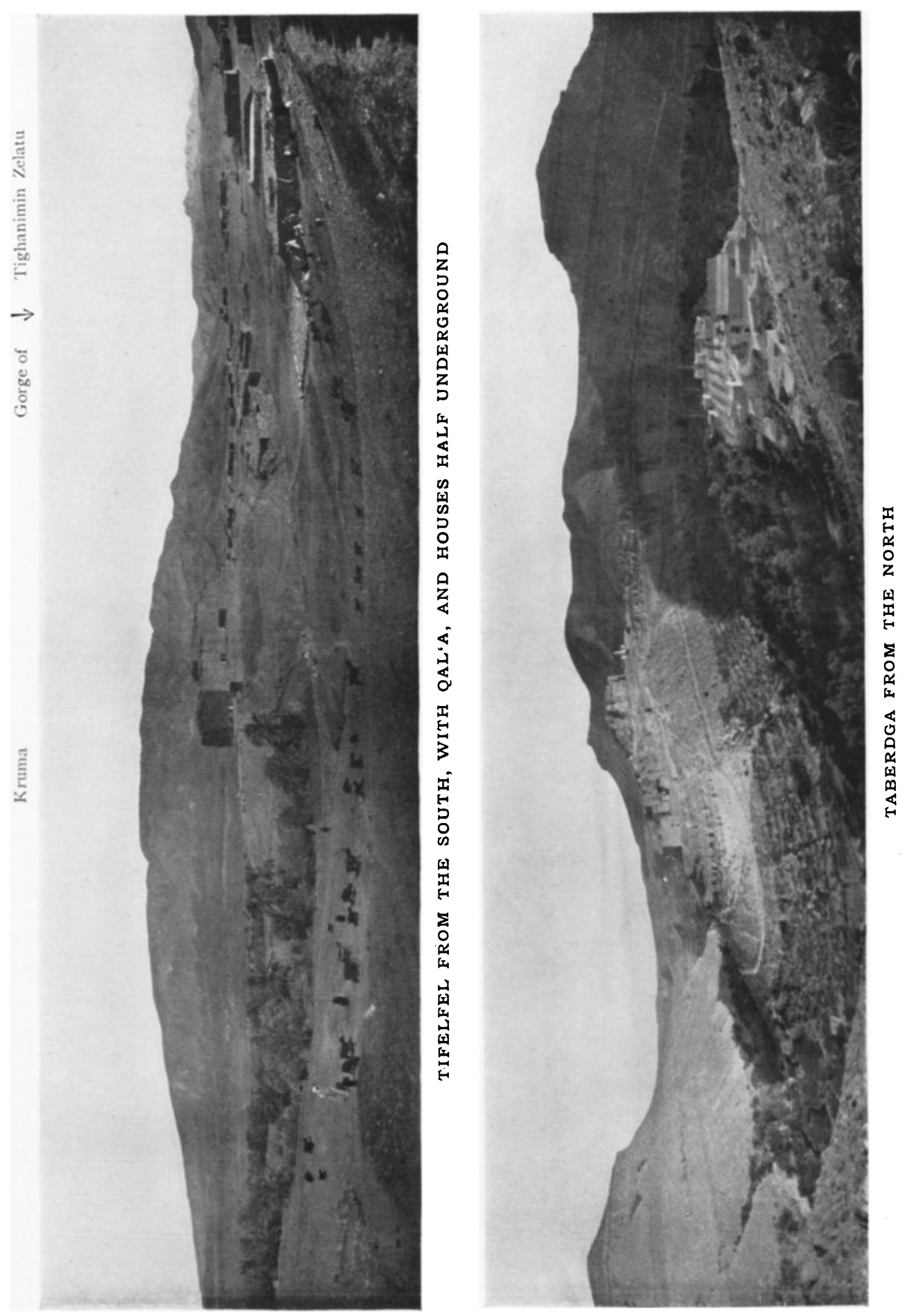

This content downloaded from 137.99.31.134 on Mon, 27 Jun 2016 04:11:07 UTC All use subject to http://about.jstor.org/terms 
With the exception of these two clocks, I have heard of but one other water-clock of the sinking type from North Africa, a type to be found in India, Burma, and Ceylon. Mr. Budgett Meakin gives a brief reference to this type in his work on 'The Moors' (p. 403), and he also alludes to a Moor who manufactured water-clocks at Toledo for astronomical calculations in his 'Life in Morocco' (p. 374).

A different type of clepsydra, however, has been reported from North Africa, namely, one in which the bowl is filled and allowed to empty upon the principle of an hour-glass. James Richardson ("Travels in the Great Desert of Sahara,' I, p. I85) noted an earthenware specimen at Ghadames in Fezzan, also used in connection with irrigation; Berthelon and Chantre report an evacuating clock, still known by a Greek name "cadous" ( $\kappa a ́ \delta o s)$, from Qabes in Southern Tunis; while El Bekri in the eleventh century found this type, then known as "cadès," at Tozer, some I 20 miles to the west of Qabes. It seems remarkable that the two types of water-clock should be found in such comparatively close proximity to one another, for although Sir Everard im Thurn informs me that he has seen and collected a specimen in Ceylon, used alternately as an evacuating and sinking clock, Mr. Harding-King's specimen could certainly not have been so used.

From such scanty evidence as I have as yet been able to collect it is difficult to trace the origin of the Beni Ferra clock unless we consider that the fairly numerous remains, some of them in use to-day, of rock-hewn Roman "saqiyas" to be found in the Aures and, as in the gorge of $\mathrm{El}$ Qantara, in the neighbourhood of the massif, may indicate that the waterclock was used when these were new to apportion the flow of their waters as it is at Beni Ferra and elsewhere to-day.

Though the land of the Shawiya farmers is very carefully tilled, compared with that of their neighbours of the plains, the tools with which they work are of the roughest description. The smaller of the two wheelless ploughs in use is nothing more than an enlarged prehistoric hoe, its ancestor, fitted with a steering handle; the larger variety, drawn by a pair of mules, is but slightly more elaborate and resembles closely models I have seen of the modern Cyprian plough. Both are fitted with iron shares.

The ceremonies with which the ploughing season commences, upon which I have published a few notes elsewhere, will probably, when carefully examined, be found to form a part of an ancient cult such as that of which I shall point out some survivals at the end of this paper.

In addition to cereals and vegetables the Shawiya cultivate a large number of fig and fruit trees as well as olives, from which latter, in the west, centre, and east of the massif, a considerable amount of oil is extracted. The two methods of obtaining this oil furnish excellent examples of the survival of ancient arts and crafts in the cultural island of the Aures. I gave some description of them in Man of August r920. 
The more modern of these methods, in which the pressure is exerted by means of a lever formed of a tree-trunk weighted with a stone, which we found in use at Beni Ferra, so closely resembles a press̄ of, at latest, Roman times, reconstructed by Prof. J. L. Myres as a result of his work among the ancient sites of Tripoli, that illustrations of the two would be almost interchangeable (Proc. Soc. of Ant. of London, Second Series, I7, 286).

This olive press at Beni Ferra is especially interesting as an example of the influence of geography and climate upon the persistence of ancient crafts in the Aures, for whereas in the high-lying village of Beni Ferra, enjoying a greater rainfall than the country at the foot of the hills, olives still flourish to such an extent as to keep this and other presses at work, in the now dry and barren stony desert below, at an altitude of 1640 feet, a mile or two to the south west of El Qantara oasis, are to be found sites, evidently dating from Roman times, upon which fashioned weight-stones and press-beds of exactly similar olive-mills can be seen, although the olive has long since ceased to flourish any nearer than at Beni Ferra, some ro miles in a direct line across hills which rise to some 4320 feet above the sea.

The more primitive system of olive pressing was noted in the Jebel Shershar, in which the olives are crushed upon a hardened floor by means of a heavy stone pushed to and fro by the foot of man; then boiled, and enclosed in baskets, they are pressed for the extraction of the oil between two slabs of stone, upon the upper of which stands a woman transferring her weight from one foot to the other while the oil exudes into a circular trench chipped in the lower stone. 'This must, I should imagine, be one of the oldest systems of obtaining oil that can be found in use to-day.

Living, as was our habit, in native huts in the villages themselves, we found ample opportunity of studying Shawiya arts and crafts, and, owing to the presence of my wife, we were able to observe those of the women as closely as those of the men, though the Moslem Berber woman, despite the far greater freedom she enjoys than the poor drudge of a desert oasis, could scarcely be expected to gratify the curiosity of a male European travelling alone. Thus, between us, my wife and I were able to observe in detail their methods of spinning, one of which, I believe, has not yet been described, and weaving upon a simple vertical hand-loom, in which no shuttle is employed, for more advanced looms, such as those of Tlemsen and the card loom for ribbon used at Constantine and Tunis, have not yet penetrated into the Aures. Nevertheless the material woven for burnouses, pillows, and rugs is well made and durable, as is the tentcloth and sacking manufactured upon a very primitive horizontal loom, often rigged up in the village street, in connection with which a rudimentary shuttle is employed, merely a plain stick around which the weft is coiled. Every Shawiya woman we have met is skilled in the art of 
weaving. The very great majority are also capable of manufacturing for themselves such simple articles of pottery as they require for household use. These bowls, dishes, and stew-pots are fashioned by hand without the aid of a wheel, and the vessels when nearly dry are polished with a snail-shell or smooth pebble to give them an even surface. After drying in the sun a number of pots are placed upon a heap of stones and covered with brushwood and refuse, the burning of which bakes the vessels beneath it.

In most parts of the massif a coating of varnish, consisting of shellac bought from Kabyle pedlars or the gum of a local juniper (Funiperus oxycedrus), which is applied while the pot is still hot from the baking, is all the ornament added; but in some villages, especially at Beni Ferra, a number of bowls are decorated with very rough patterns in reddish earth laid on with a doubled straw. These patterns, far more primitive than those employed by the Kabyle Berbers near the coast, though crude, are interesting in that two at least of them seem to constitute traces of a very ancient Libyan cult.

The first of these, two lines of herring-bone forming two sides of a triangle, is now known to the natives as "jerida," or palm-branch, and it is very commonly to be found upon such articles of pottery as are decorated in the Aures, and, almost universally, in the facial tattoo marks of the women. In it Dr. Bertholon (' La Berbérie Orientale,' p. 482) sees a direct connection with the sign of Ta-Nit or Neith, the goddess of Sais in the Nile Delta, one of the earliest Egyptian goddesses, who was reported to have been introduced there from Libya, whose worship was adopted by the Phœnician settlers at Carthage, and whom Herodotus and other classical writers have identified with Athena.

In addition to this design, another, a line resembling an inverted $\mathrm{W}$, known to the Shawiya as the "scorpion," is also to be found upon the pottery and is used in tattoo, and may possibly be a relic of the days when, according to Sir E. A. Wallis Budge, "the scorpion was venerated in Egypt at a very early period," and "was sacred to Isis," which divinity had assumed the attributes of Neith ('Gods of the Egyptians,' 2, 377). There is, however, no proof available that the veneration of the scorpion came from the west. But whether or not we are prepared to accept the flimsy evidence of Shawiya designs in attempting to establish a connection with a former cult of Neith, we have further traces of it in certain ceremonies and fêtes observed in the Aures which appear to be somewhat more clear.

It is well known that in parts of Barbary there exist many ceremonies and rites now believed by the natives who perform them to constitute a part of the ritual of Islam, but which in reality are of much greater antiquity. The persistence of these rites seems due to the physical features of the land, for we have it on the authority of Dozy that at the time of the Arab conquest Sidi Oqba ben Nafi, the eastern general, 
preferred to work upon the superstitions of the hill people in his efforts to introduce his faith among them, rather than to attempt to carry that faith by force of arms into such natural fortresses as, for example, the Aures massif. In such an environment as I have endeavoured to describe, therefore, relics of a former cult may well be expected to survive.

Sir E. A. Wallis Budge tells us that in Egypt a "very important festival was that kept in the spring, on the birthday of Osiris, the son of Isis-Net, which the late Dr. Brugsch identified with the birthday of the spring sun" ('Gods of the Egyptians,' I, 463). Dr. Budge, recalling that in ancient times Neith of Saïs had been referred to as the "mighty mother," states ("Gods of the Egyptians,' I, 457) that the chief characteristics of her cult must have been those of a local Delta or Libyan goddess of Nature, probably including ceremonies intended to represent the processes of generation and reproduction.

We may, therefore, regard as a possible survival of her worship the Spring fête still observed by the Shawiya of Mena'a and the Abdi valley. On a date at the end of our February (the Shawiya, incidentally, use the Roman names of the months) the women and girls of Mena'a go overnight to the wooded hills north of the village and pass the night in the open, cutting and tying up into faggots firewood from the stunted trees around. Next morning a crowd of men and boys from the village go out to escort the women home to the music of drum and hautboy and the firing of blank charges from gun and pistol, the women carrying their loads of faggots and giving vent to the long-drawn quivering cry of joy, identical with that of ancient Greece, which, in the opinion of Herodotus, the Libyan women uttered very sweetly.

Each woman brings with her a fresh young shoot of some mountain tree or bush and wears in her head-dress a few blades of young green corn, the boys also carrying some such emblem of budding life as a shoot of pine. Every now and then the procession halts by the wayside to allow the women to lay down their burdens and to watch the antics of one of the young girls who performs a danse du ventre to the strains of the "band."

Upon arrival at the village the women disperse to attire themselves in their best, while the band, with a goodly number of followers, visits first the zawiya of a celebrated maraboutic family, and, after playing before it and at one or two other places in the village, finally takes up a position in an open space on the steep slope among the houses. Here it is rejoined by the women, who sit in a prominent position-but apart from the men-to listen to the drum and hautboy and watch the efforts of youthful danseuses.

Upon the second and third days of the fête similar ceremonial takes place, but the place of honour at the band concert is given to the very young girls, even the smallest of children being brought to the ceremony attired in bright clean garments and masses of silver ornaments borrowed from their relatives. 

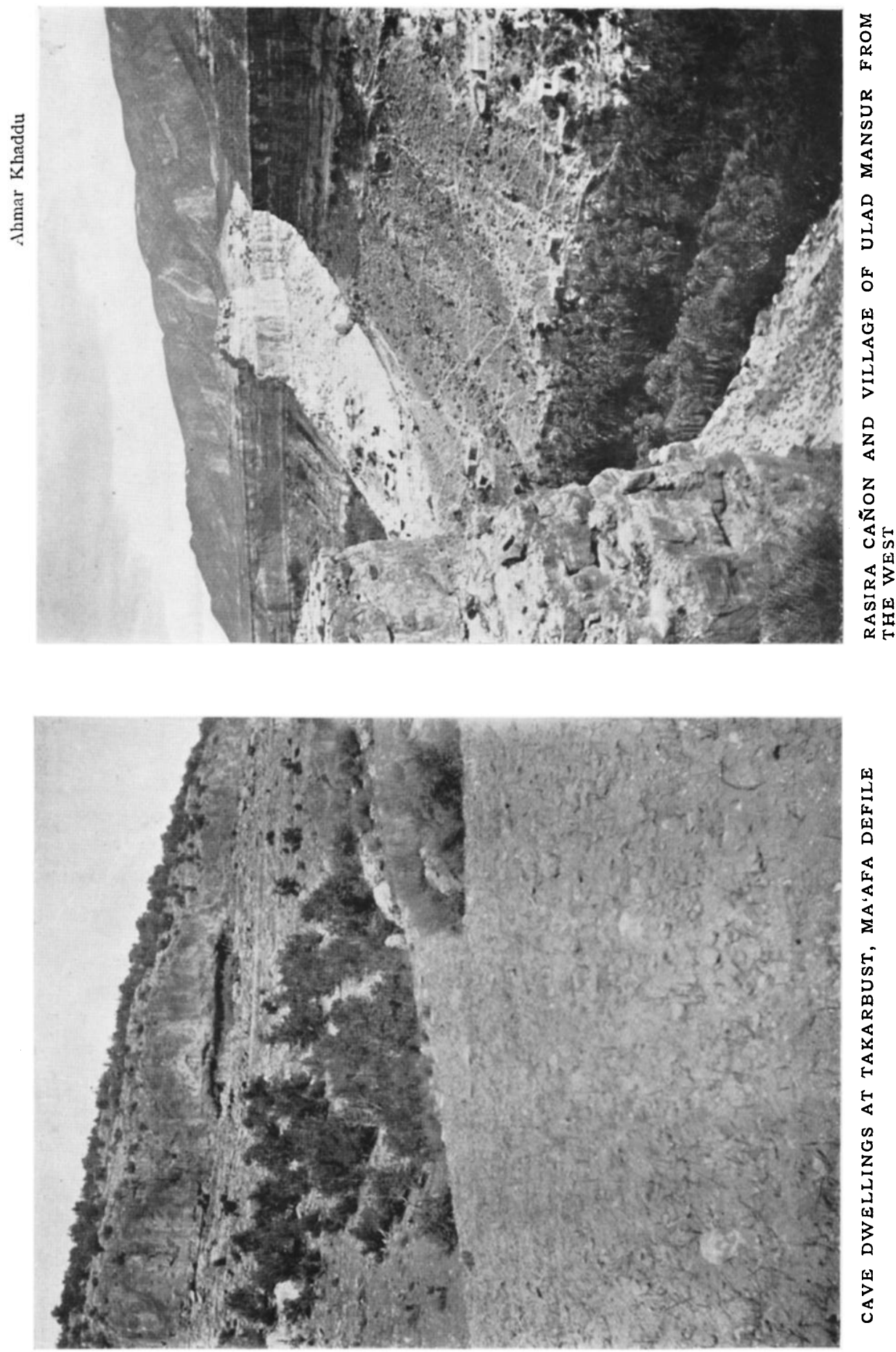

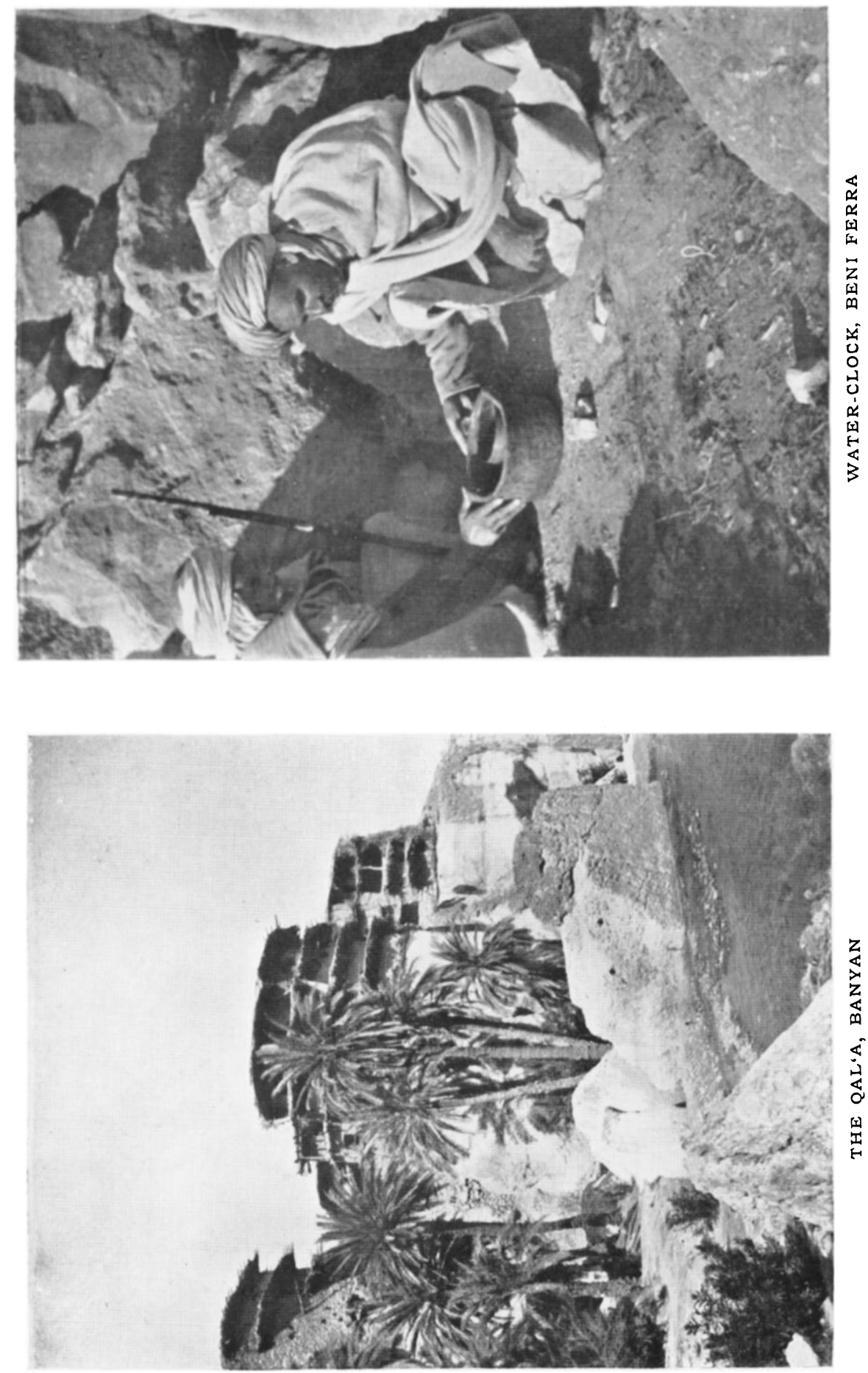

This content downloaded from 137.99.31.134 on Mon, 27 Jun 2016 04:11:07 UTC All use subject to http://about.jstor.org/terms 
Upon each day, in the evening, is played the ancient game of "koora," which is widely played in the spring in many areas of North Africa. This game resembles a primitive hockey, and is played with heavy clubs or branches of juniper, etc., and a stone.

At Mena'a the village is divided into two sections, east playing west, but in other villages of the Wad Abdi a game of married versus single is played before large crowds of both sexes. The game is most violent-I have myself rendered first aid to a number of casualties resulting from it -and it not infrequently degenerates into the battle which, even in its milder forms, it resembles. But though this game is played by men and boys (and sometimes by girls in the seclusion of their houses), elsewhere in North Africa, at Mena'a, in the Abdi valley and other parts of the Aures, it is played quite openly and before spectators by the women and girls at the feast of the Spring. If scarcely so violent as the "koora" of the men, the game is played with great vigour and spirit by the gentler sex, and there seems little doubt that it is a persistence of some such ritual as that to which Herodotus (iv. I80) refers when he describes the ceremonies of the natives around Lake Tritonis (the modern Shotts of southern Tunis), some 150 miles to the south-east of the Aures massif.

Prof. J. L. Myres has kindly furnished me with the following translation of Herodotus' passage: "The Ausean maidens keep year by year a feast in honour of Athena, whereat their custom is to divide into two parties and struggle against one another with stones and sticks, saying that they are performing their ancestral rites to the deity who was born in that place whom we (Greeks) call Athena. If any of the girls die of their injuries they say that they are not true maidens. Before the signal is given for them to fight they do this in common : they dress up the prettiest girl on each occasion in a Corinthian helmet and full Greek armour, put her in a car, and draw her all round the lake."

That Herodotus uses the word "stones" in the plural is by no means extraordinary, for I have myself often seen several games in progress at the same time in one of the few available level spaces in an Aures village; while the dressing up of a pretty girl by the Auseans may well be considered to have survived in the gaily-decked dansensses who perform to-day at the spring feast of the Shawiya.

Other traces of the worship of Neith or Athena thus referred to by Herodotus some twenty-four centuries ago, may be found by careful examination of the customs of the Shawiya within the ramparts of the Aures massif. But the search for such traces, if it is to be made at all, must not long be delayed. The student who would examine in detail the evidence of the conservative influence of the geography of the Aures upon the culture of its Berber inhabitants - a very few items of which evidence I have endeavoured to put forward in this paper-should lose no time in setting to work. Roads open to vehicular traffic are to be laid through the heart of the hills; thus linking their secluded valleys with the outer 
world, and many Shawiya, leaving for the first time their mountain homes, have served France upon the fields of Flanders and the Argonne, to bring back with them to their villages among the crags more seeds of change and progress than have penetrated to the cultural island of the Aures for untold ages in the past.

I cannot conclude this paper without expressing my deep sense of gratitude for the facilities granted us by the French authorities and for the ready assistance and kindly hospitality which we have ever received at the hands of French officers-military and administrative, European and native-during our wanderings in and around the Aures. Without such assistance, for which we have never appealed in vain, we could scarcely have undertaken our researches at all; with it, difficulties vanished and our path became easy and delightful.

Before the paper the President said: Mr. Hilton-Simpson has been travelling in Algeria, and has been devoting himself especially to the study of primitive surgical instruments. During that time he has also been able to study the effect of geography upon the character of the people, and I have very much pleasure in introducing him to you and asking him to give his lecture.

\section{Mr. Hilton-Simpson then reaa the paper printed above, and a discussion followed.}

Mr. HARDING KING : I am afraid my knowledge of the Aures massif is confined to the immediate neighbourhood of El Qantara. It has been very interesting to see how the peculiar geographical conditions there have tended to keep the Shawiya as a race apart ethnographically. Those irrigation methods in North Africa are an interesting study. As far east as the Egyptian oasis of Kharga we find long horizontal infiltration galleries cut underground through a water-bearing stratification, which are also found as far west as the Twat group of oases in the south-west of Algeria, showing, I think, a connection in the irrigation methods between the two districts. Those curious water-clocks which you get in Algeria are, I believe, a later idea than the system which is in use in the Egyptian oasis. There, in order to estimate the time, the natives turn themselves into a sort of human sundial, and by means of a rather complicated table are then able to estimate the time of day. I think that is a rather more primitive method than the water-clocks which we have had described to-night.

Prof. J. L. MYRES: It is a very great pleasure to have the opportunity of expressing what one feels at hearing this closely packed summary of one section of the valuable work which Mr. Hilton-Simpson has been doing. He has illustrated very clearly the manner in which the gradual shift in intensity of the different factors which go to make the climate of the Aures has affected the vegetation, through the water régime in the first place, and through the vegetation and animal life, the shape which the struggle to maintain human societies has taken. He compared some of the types of scenery, which he showed us, with European forms, some with Asiatic forms, and for some, as he indicated, one would have to go quite far away and find parallels from other parts of Africa. One thing which struck me particularly was how the less dry sections of the Aures recall the similarly constructed parts of the Spanish peninsula, particularly in the north, and even some of the most completely dried-up and vegetation-less 